\title{
RECOMMANDATIONS AUX AUTEURS
}

Les auteurs peuvent soumettre leur manuscrit en anglais ou en français et doivent l'envoyer au rédacteur en chef par courriel (nsis@dal.ca et oceans2@ns.sympatico. ca). Le titre du manuscrit doit être suivi des noms de tous les auteurs, leurs adresses respectives et leurs adresses de courriel. Un résumé doit suivre qui comptera au plus 200 mots. Si approprié, il doit y avoir des sections tel que l'introduction, les méthodes, les résultats, la discussion, les conclusions et les références bibliographiques. L'orthographe doit suivre Le Grand Robert, et il est recommandé de se servir du Système international d'unités. Des frais de 25,00\$ par page sont présentement imposés, à moins que tous les auteurs sont membres du Nova Scotian Institute of Science. (Les frais d'adhésion pour membres réguliers sont 25,00\$ par an, et pour étudiants sont 10,00\$ par an.) Des tableaux, des illustrations et des photos en noir et blanc peuvent être inclus et seront reproduits sans frais supplémentaires. Au format copie papier du journal, les coûts de reproduction en couleurs seront aux frais des auteurs, et seront environ $500 \$$ par planche qui peut être une seule photo ou un collage. Chaque tableau ou illustration doit porter un titre et une légende auto-explicative.

Veuillez consulter des exemplaires du Journal pour vérifier le format du manuscrit. Chaque page doit être numérotée. Les références bibliographiques doivent être en ordre alphabétique et doivent montrer le nom complet de la revue, et si approprié, les numéros des revues, comme les exemples suivants:

Nielsen, K.J., \& France, D.F. (1995). The influence of adult conspecifics and shore level on recruitment of the ribbed mussel Geukensia demissa (Dillwyn). Journal of Experimental Marine Biology and Ecology 188 (1):89-98.

Cushing, D. \& Walsh, J. (1976). The Ecology of the Seas. W. B. Saunders Company, Toronto.

Lee, G.F. (1975). Role of hydrous metal oxides in the transport of heavy metals in the environment. In: Krenkel,P.A.(ed.),Heavy Metals in the Aquatic Environment. Pergamon Press, Oxford, pp. 137-147.

Communication personnelle: Smith A.J. (2001, pers. comm.) in text.

Document sur un site web: Auteur (l'année de publication) titre, URL et la date de consultation.

Les auteurs sont responsables pour la revue des épreuves en placard dans les plus brefs délais. Une reproduction électronique de l'article en format PDF sera fournie gratuitement aux auteurs. Comme un des avantages d'adhésion, les membres du NSIS reçoivent chaque numéro du journal au format copie papier. Des exemplaires des numéros spéciaux de la revue sont en vente chez NSIS aux frais établis par NSIS. 


$\begin{array}{ll}\text { President: } & \text { Tom Rand } \\ \text { Vice-President: } & \text { Patrick Ryall* } \\ \text { Past President: } & \text { Michelle Paon } \\ \text { Secretary: } & \text { Linda Marks }\end{array}$

$\begin{array}{ll}\text { Treasurer: } & \text { Angelica Silva } \\ \text { Editor: } & \text { Peter G. Wells } \\ \text { Librarian: } & \text { Michelle Paon } \\ \text { Webmaster: } & \text { Suzuette Soomai } \\ \text { Publicity: } & \text { Vacant }\end{array}$

Councillors: Henry (Hank) Bird (Writing Competition Coordinator), Leigh Ann Bishop (Sci. Teacher's Rep), Robert Boudreau (Mentorship), Kevin Hewitt, Ron MacKay, Rick Singer, John Young

\section{Student Representative: Allison Chua}

Observers: Jeff Gray (Nova Scotia Museum)

\section{INSTRUCTIONS TO AUTHORS}

Papers may be submitted in either English or French and should be sent electronically to the Editor at (nsis@dal.ca and oceans2@ns.sympatico.ca). The title should be followed by names, addresses and e-mails of all authors. An abstract of up to 200 words should follow. As appropriate, sections devoted to introduction, methods, results, discussion, conclusions and references should be included. Canadian spelling and SI units should be used wherever possible. There is currently a page charge of $\$ 25$ per page but this will not be levied if all authors are NSIS members (Membership costs $\$ 25$ per year for regular members and $\$ 10$ year for students.) Tables, figures and black and white photographs may be included and will be published without an extra charge. Publication of colour figures in any hard copy of the journal will incur a charge that must be borne by the author and will likely be in the range of $\$ 500$ per plate which may be a single photo or a collage. All tables and illustrations should have a title and a self-explanatory legend, sent in separate files at 300 dpi or higher.

Refer to more recent issues of the Journal for general layout of a paper. Pages should be numbered. References should be in alphabetical order - name first, initials after, and give the full title of the journal and issue numbers where appropriate, thus:

Nielsen, K.J., \& France, D.F. (1995). The influence of adult conspecifics and shore level on recruitment of the ribbed mussel Geukensia demissa (Dillwyn). Journal of Experimental Marine Biology and Ecology 188 (1):89-98.

Cushing,D.\& Walsh,J.(1976). The Ecology of the Seas.W.B. Saunders Company, Toronto.

Lee, G.F. (1975). Role of hydrous metal oxides in the transport of heavy metals in the environment. In: Krenkel, P.A. (ed.), Heavy Metals in the Aquatic Environment. Pergamon Press, Oxford, pp. 137-147.

Personal Communication: Smith A.J. (2001, pers. comm.) in text.

Website Citation: Author (year) title, URL and date accessed.

Authors are responsible for correcting and returning proofs promptly. Authors will be provided with a PDF of their paper, free of charge. NSIS members receive a hard copy of the Proceedings as part of their annual membership. Copies of Special Issues of the NSIS proceedings may also be purchased from NSIS at a charge established by the NSIS. See the NSIS website http://www.chebucto.ns.ca/Science/NSIS/ for details. 